\title{
Korkeakoulujen uudet tehtävät
}

Korkeakoulujen tehtävät aikuiskasvatuksen alueella ovat laajentuneet nopeasti parin viimeisen vuosikymmenen aikana kaikissa teollistuneissa maissa. Tästä syystä mm. OECD on katsonut aiheelliseksi kartoittaa aikuisopiskelijoiden lukumääriä eräiden maiden korkeakouluissa ja tarkastella, mikä korkeakoulujen asema ja tehtävät ovat nykyisin aikuisen elinikäisen oppimisen edistämisessä. Kartoituksen tulokset on julkaistu vuonna 1987 ilmestyneessä raportissa "Adults in Higher Education".

Aikuisopiskelijoiden määrällinen vertailu on tietysti hankalaa, koska eri maiden korkeakoulujärjestelmät poikkeavat jonkin verran toisistaan. Myös aikuisopiskelijoiden erottaminen muista korkeakouluopiskelijoista on joissakin tapauksissa vaikeaa. OECD:n raportissa aikuisopiskelijan kriteeriksi on otettu se, että henkilö on ollut vähintään 25 -vuotias tai sitä vanhempi, kun hän on tullut uutena opiskelijana korkeakouluopintoihin mukaan. Raportin mukaan tällaisten aikuisopiskelijoiden prosenttiosuus kaikista korkeakouluopiskelijoista oli lukuvuonna 1981-82 Yhdysvalloissa 24.0, Isossa Britanniassa 16.7 ja Suomessa 19.6. Selvästi eniten aikuisopiskelijoita oli kuitenkin Ruotsissa, missä heidän osuutensa oli peräti 54.6 \%:a. Vaikka lukuihin on suhtauduttava varovasti, niin joka tapauksessa on selvää, että aikuisopiskelijat muodostavat nykyisin oman erityisen ryhmänsä korkeakouluissa ja että heidän osuutensa on ilmeisesti yhä lisääntymässä. Raportin mukaan korkeakoulujen tehtävät aikuiskasvatuksessa ja sen mukaan tällaiseen opetukseen osallistuvat voidaan jakaa kolmeen ryhmään.

Ensimmäisen ryhmän muodostavat ne, jotka osallistuvat olemassa olevien koulutusohjelmien ja arvosanojen opiskeluun. Suomessa tällaisesta opetuksesta käytetään yleensä nimitystä arvosanaopetus. Sitä antavat nykyisin kaikissa korkeakouluissa toimivat täydennyskoulutuskeskukset, lähes koko maan kattavan verkoston omaavat kesäyliopistot sekä eräät muut aikuiskasvatusorganisaatiot, esim. kansan- ja kansalaisopistot.

Pääosa tästä opiskelusta on tähdännyt approbaturia vastaavan opintokokonaisuuden suorittamiseen, mutta muidenkin arvosanojen - jopa tutkintojen suorittaminen - on nykyisin mahdollista myös aikuisopiskelijoille hakeutumalla korkeakoulun ylimääräiseksi opiskelijaksi tai ns. erikoistapaukseksi. Riitta Väisäsen mukaan arvosanaopiskelijoiden määrä oli vuonna 1987 noin 25000 henkilöä. Paineet tähän suuntaan näyttävät vain lisääntyvän. Perustutkintojen lisäksi tarpeet yliopistollisten jatkotutkintojen suorittamiseen näyttävät myös lisääntyneen työelämässä. Esimerkkinä tästä ovat mm. eräiden yritysten tukemat lisensiaattija tohtorikoulutusohjelmat.

Toisen ryhmän muodostaa sellainen korkeakoulujen järjestämä tutkintoihin tähtäämätön koulutus (liberal studies), jota annetaan yliopiston tai korkeakoulun ulkopuolisille väestöryhmille (extra-mural activities). Erityisesti Yhdysvalloissa ja Isossa-Britanniassa on tällaisella opetuksella pitkät perinteet. Meillä tällainen toiminta on ollut vähäistä ja satunnaista. Esimerkkinä voidaan mainita $\mathrm{mm}$. Helsingin yliopiston kansansivistystoimikunnan harjoittama luento- ja kurssitoiminta. Maailman tieteellistyessä tulisi korkeakoulujen tiedostaa myös tämä tehtäväalueensa. Kysymys on tieteen popularisoinnista ja sen uusien saavutusten tiedottamisesta laajemmille väestöpiireille. Arvosanaopetus on ehkä osaltaan pyrkinyt tyydyttämään tätä tehtävää, mutta se ei yksin riitä, koska sen yhteydessä ei voida ottaa riittävästi huomioon eri väestöryhmien erilaisia tarpeita ja lähtökohtia.

Kolmannen ryhmän korkeakoulujen aikuisopetuksessa muodostavat ammatillinen täydennys- ja uudelleenkoulutus. OECD:n raportin mukaan tämä on nopeimmin viime aikoina laajentunut tehtäväalue. Näin on epäilemättä myös Suomessa. Kaikissa korkeakouluissa on nykyisin täydennyskoulutuskeskus ja jos otetaan huomioon myös niiden sivutoimipaikat, niin täydennyskoulutusta annetaan nykyisin 37 toimipisteen kautta. Täydennyskoulutuskeskuksissa työskenteli Riitta Väisäsen mukaan vuoden 1987 lopussa 526 henkilöä ja täydennyskoulutuksen "liikevaihto" kaikissa korkeakouluissa oli yhteensä runsaat 130 miljoonaa markkaa. 
Opiskelijoita korkeakoulujen ammatillisilla kursseilla ja työllisyyskoulutuksessa oli vuonna 1986 noin 30000 henkilöä. Ammatillinen täydennyskoulutus on selvimmin seurausta yhteiskunnan nopeasta muuttumisesta. Korkeakoulujen on pakko kantaa vastuuta kouluttamiensa henkilöiden ammatillisesta pätevyydestä myös sen jälkeen, kun he ovat jo sijoittuneet työelämään. Tämä tehtäväalue asettaa korkeakouluille aivan uusia, aikaisemmasta poikkeavia vaatimuksia. Niiden tulee entistä aktiivisemmin seurata, mitä työelämässä tapahtuu ja kehittää omaa opetus- ja tutkimustoimintaansa sen mukaan. Oikeastaan kehityksen seuraaminen ei edes riitä, vaan korkeakoulujen tulee olla mukana yhteiskunnallisessa kehittämistoiminnassa ja antaa siihen oma panoksensa. Korkeakouluilla riittää runsaasti tehtäviä ammatillisessa täydennyskoulutuksessa myös sen takia, että monilla toimialoilla, joihin nykyisin vaaditaan korkea-asteen tutkinto, työskentelee runsaasti henkilöitä, jotka ovat aikoinaan sijoittuneet näihin tehtäviin ilman alan peruskoulutusta. Vaikka he ovat kokemuksensa kautta kehittyneet ammattinsa taitaviksi ammattimiehiksi ja -naisiksi, niin he ovat usein kiinnostuneita korkeakoulujen täydennyskoulutuksesta, koska se parantaa heidän ammattipätevyyttään ja antaa heille valmiuksia oman työnsä ja toimialansa kehittämiseen.

Akateemisillakin aloilla esiintyvä työttömyys on aiheuttanut jo kerran peruskoulutettujen keskuudessa uudellenkoulutustarvetta. Tällöin on yleensä kysymys joko uusien koulutusohjelmien kehittämisestä tai vanhojen ohjelmien uudenlaisesta yhdistelemisestä. Tällaisen koulutuksen suunnittelu vaatii korkeakouluilta kykyä löytää uusia "markkinarakoja" perinteisten koulutusammattien välimaastosta.

Korkeakouluissa opiskelevien aikuisopiskelijoiden kokonaismäärä ylitti jo vuonna 1987 selvästi 50000 opiskelijan rajan. Korkeakoulujen täydennyskoulutus ja arvosanopetus on laajentunut ja kasvanut meillä melko suunnittelemattomasti. Tästä on ollut seurauksena monia ongelmia mm. tarjonnan päällekkäisyys ja resurssien epätarkoituksenmukainen käyttö.
Arvosanaopetuksen järjestäminen on joskus niin "villiä", etteivät edes ainelaitokset itse pysty suoralta kädeltä sanomaan, missä kaikkialla opetusta järjestetään heidän vaatimustensa mukaisesti. Tällaisen tuloksen sai eräs täydennyskoulutuskeskus, kun se tiedusteli asiaa niiltä. Pahimmillaan tilanne voi olla se, että arvosanaopetusta järjestetään $20-30$ paikkakunnalla hyvinkin kirjavan opettajakunnan voimin. Kuka tällöin voi vastata ja huolehtia opetuksen tasosta?

Eräs ongelma on resurssien oikea suuntaaminen. Nykyisin meillä on jo varsin kattava ja mittava täydennyskoulutuskeskusten sekä kesäyliopistojen verkosto. Nämä organisaatiot ovat kuitenkin lähinnä toiminnan organisoijia, eivät varsinaisen toiminnan, eli opetuksen toteuttajia. Siihen tarvittavat resurssit löytyvät vain korkeakoulujen laitoksilta. Tämä tulisi suunnittelijoiden, niin opeteusministeriössä kuin täydennyskoulutuskeskuksissakin muistaa. Laitosten henkilökunta on toiminnan kehittämisessä avainasemassa. Arvosanaopetus ja täydennyskoulutus ei kuitenkaan sisälly muuta kuin vaatimuksena - laitosten toimintaan. Siihen osallistuminen on opetushenkilökunnan oman harrastuksen varassa; sitä ei huomioida mitenkään heidän opetus- ja muissa velvollisuuksissaan. Jos korkeakoulut aikovat olla mukana aikuisopetuksen kehittämisessä, niin se edellyttää tätä varten palkattavien suunnittelijoiden lisäämistä nimenomaan laitostasolla ja/tai täydennyskoulutuksen sisällyttämisestä laitosten nykyisen henkilökunnan työ- ja virkavelvollisuuteen. Tämä voisi tapahtua käytännössä esim. siten, että joku tai jotkut laitoksen henkilökunnasta osallistuisivat vuorovuosin tai -ajoin virkavelvollisuuteensa kuuluen oman alansa täydennyskoulutuksen suunnitteluun ja toteuttamiseen. Tästä voisi olla seurauksena korkeakoulujen ja työelämän entistä parempi ja tiiviimpi yhteistyö, joka epäilemättä auttaisi korkeakouluja kehittämään myös perusopetustaan relevantimpaan suuntaan.

Jukka Tuomisto 